\title{
The Study of $\beta$ HCG Level Along With General Biochemical Profile in Pre-eclampsia
}

\author{
${ }^{1 .}$ Dr Sumitra Yadav, ${ }^{2 .}$ Namrata Shrivastava, ${ }^{3 .}$ Sangeeta Paneri, ${ }^{4}$ Preeti Pawar \\ 1.Associate Professor Department Of Obstetrics And Gynecology, 2. Senior Resistrar Department Of \\ ObstetricsAnd Gynecology, 3. Associate Professor, Department Of Biochemistry, 4.Resident doctor, department \\ of Obstetrics And Gynecology M.G.M. Medical College, Indore, M.P.
}

\begin{abstract}
:
Objective-Preeclampsia is one of the leading cause of maternal mortality and morbidity worldwide. The purpose of this study was to determine the level of $\beta$ hCG and other biochemical markers in preeclampsia and in normotensive patients.

Method - This was a prospective study conducted on 50 preeclamptic (case)and 50 normotensive pregnant women (control) in obstetrics and gynaecology department of M.Y. hospital. Level of $\beta$ hcg and other biochemical markers between case and control was compared with chi-square test. P-value $<0.05$ was considered significant.

Result- In our study mean $\beta$ hcg level in preeclamptic women( 27,802.51mIU/L) was higher than normotensive pregnant women $(12,551.08 \mathrm{mIU} / \mathrm{L})$ with $p$-value $<.05$. Level of other biochemical markers triglycerides, total cholesterol were also higher in preeclamptic women compared to normotensive pregnant women with $p$-value $<0.05$.

Conclusion- The result of this study show that level of $\beta$ hcg is significantly higher in preeclampsia then in normotensive pregnant women. Level of triglyceride and total cholesterol also have significant difference in both group with higher level in preeclampsia.
\end{abstract}

\section{Introduction}

Pre-eclampsia is a pregnancy specific disorder characterized by newly onset of blood pressure more than $140 / 90 \mathrm{mmHg}$ in at least two consecutive occasion and proteinuria ( $>300 \mathrm{mg}$ per 24 hours collection) in third trimester of pregnancy ${ }^{[1]}$.

Preeclampsia complicates about $2-8 \%$ of all pregnancies. Worldwide about 76,000 pregnant women die due to preeclampsia and related hypertensive disorders ${ }^{(2,3)}{ }^{(1)}$. It is responsible for $25 \%$ of all fetal growth retardation and $15 \%$ preterm birth in developed countries ${ }^{[1]}$. The incidence of pre-eclampsia in India is about $8-10 \%{ }^{[1]}$ and maternal mortality due to preeclampsia reported to be $8 \%{ }^{(1)}$. Most current hypothesis regarding the pathophysiologic mechanisms of pregnancy-induced hypertension point to early placental abnormalities. Human placenta synthesizes steroid, protein, and glycoprotein hormones throughout gestation Since it is postulated that preeclampsia is likely a trophoblastic disorder, it may be essential for understanding of this disease, to investigate the pathologic and secretory reaction of the placenta $^{(4) .}$ Twin pregnancies and molar pregnancies produce higher levels of hCG and they are associated with a higher incidence of preeclampsia than uncomplicated singleton pregnancies ${ }^{(4)}$. An association was reported between preeclampsia and elevated third trimester hCG levels ${ }^{(4)}$.

The human chorionic gonadotropin (hCG) is a glycoprotein composed of two non covalently linked subunits, $\alpha$ and $\beta$, and is produced by syncytiotrophoblast cells of the placenta. Maternal serum hCG peaks at $8-10 \mathrm{wk}$ of gestation and then declines to reach a plateau at $18-20 \mathrm{wk}$ of gestation. The free $\beta$-subunit can derive from three sources namely, direct trophoblast cell production, dissociation of hCG into free $\alpha$ - and free $\beta$-subunits, and by macrophage or neutrophil enzymes nicking the hCG molecules The free $\beta$-hCG circulating in maternal serum corresponds to only about $0.3-4 \%$ of the total $\mathrm{hCG}^{[1]}$.

In pre-eclampsia histological examination reveal focal cellular necrosis in the syncytiotrophoblast and increased mitotic activity with cellular proliferation in the cytotrophoblast ${ }^{[1] .}$ In addition the proliferating trophoblast in severe preeclampsia is rapidly transformed into syncytiotrophoblast within 72 hours. The normal placenta differentiates during pregnancy with the cytotrophoblast dominant in early gestation and the syncytiotrophoblast dominant in late pregnancy. Placental vascular damage leading to decreased oxygen supply might result in increased hCG production by hyperplastic cytotrophoblastic cells

There is a strict relationship between PIH and elevated serum $\beta$-hCG levels, indicating that there should be an abnormal placental secretary function in patients with severe pre eclampsia. The aim of this 
present study was to find out the role of $\beta$-hCG in pathogenesis of pre-eclampsia and its association with severity of pre-eclampsia.

Pregnancy is associated with physiological hyperlipidemia but in PIH they increase two fold $(5,6)$. Abnormal lipoproteins levels are responsible for damage to endothelium that leads to high blood pressure, and proteinuria; these are important signs of $\mathrm{PIH}^{(7)}$. Association of serum lipids with gestational proteinuric hypertension is highly suggestive of a role for lipid profile analysis as a diagnostic tool.

A mild transient thrombocytopenia is seen in pregnancy due to increased platelets consumption during pregnancy Thrombocytopenia is found in 6\% of pregnancy and most common cause of thrombocytopenia in pregnancy is preeclampsia and eclampsia ${ }^{(8)}$. It is found that thrombocytopenia is associated in pregnancy with complication like abruptio placenta, preterm delivery and low apgar score ${ }^{(8)}$. Low platelets count in pregnancy is associated with abnormal activation of coagulation system and believed to reflect increased consumption of platelets ${ }^{(8)}$.

This study was designed to evaluate the relationship between level of $\beta$ hCG and general biochemical test and severity of preeclampsia.

\section{Material And Method}

The present study was conducted in department of obstetrics and gynaecology, MGM medical college Indore from Oct 2013 to April 2014. This was a prospective comparative study. This study was conducted on 50 normotensive pregnant women and 50 preeclamptic women with gestational age 28-40 weeks, between age group 18 to 30 years. Women with multiple pregnancy, diabetes mellitus, chronic hypertension, renal and cardiovascular disease and blood disorder were excluded from this study. After getting consent, $2 \mathrm{ml}$ semple of blood collected from each subject. Level of $\beta$ hCG was measured by CMIA method (chemiluminescent micropartical immunoassay). Level of triglycerides, cholesterol, platelets and serum creatinine also compared in both groups.

\section{Results}

Table1

Distribution According to $\beta$-hCG Level

\begin{tabular}{|l|l|l|l|l|}
\hline \multirow{2}{*}{$\mathrm{B}$ hcg level in $\mathrm{mIU} / \mathrm{L}$} & Preeclamptic women & \multicolumn{2}{l|}{ Normotensive pregnant women } \\
\cline { 2 - 5 } & No & $\%$ & No & $\%$ \\
\hline$<10,000$ & 00 & 00 & 13 & 26 \\
\hline $10,000-20,000$ & 28 & 56 & 29 & 08 \\
\hline$>20,000$ & 22 & 44 & 50 & 16 \\
\hline TOTAL & 50 & $100 \%$ & $100 \%$ \\
\hline
\end{tabular}

Table.2

Clinical/Biochmical parameters in normotensive pregnant women and in preeclampsia

\begin{tabular}{|c|c|c|c|}
\hline Parameters & $\begin{array}{l}\text { Normotensive Pregnant } \\
\text { women(Control) } \\
\quad \mathrm{n}=50\end{array}$ & $\begin{array}{l}\text { Preeclamptic women(case) } \\
\text { Mean } \pm \text { SD } \\
n=50\end{array}$ & $\begin{array}{l}\text { Significance } \\
\text { p-value }\end{array}$ \\
\hline Age & $25.40 \pm 3.676$ & $23.24 \pm 3.941$ & $\begin{array}{ll}\text { Not significant } & (\mathrm{p} \leq \\
0.645) & \end{array}$ \\
\hline $\begin{array}{l}\text { Systolic } \quad \text { blood } \\
\text { pressure in } \mathrm{mmHg}\end{array}$ & $120.80 \pm 2.740$ & $153.20 \pm 16.142$ & significant $(\mathrm{p} \leq 0.0001)$ \\
\hline $\begin{array}{l}\text { Diastolic blood } \\
\text { pressure in } \mathrm{mmHg}\end{array}$ & $74.32 \pm 2.21$ & $103.00 \pm 10.351$ & $\begin{array}{l}\text { Significant } \\
(\mathrm{p} \leq 0.0001)\end{array}$ \\
\hline $\begin{array}{l}\text { Serum } \beta \text {-hcg level } \\
\text { in } \mathrm{mIU} / \mathrm{L}\end{array}$ & $12,551.08 \pm 1624.28$ & $27802.51 \pm 2324.46$ & Significant $(\mathrm{p} \leq 0.001)$ \\
\hline $\begin{array}{l}\text { Serum TGs level in } \\
\mathrm{mg} / \mathrm{dl}\end{array}$ & $124.48 \pm 18.6714$ & $281.96 \pm 99.84$ & Significant $(\mathrm{p} \leq 0.000)$ \\
\hline Serum TC in $\mathrm{mg} / \mathrm{dl}$ & $143.33 \pm 25.24$ & $242.386 \pm 52.032$ & Significant $(\mathrm{p} \leq 0.001)$ \\
\hline Platelets counts & $2.474 \pm 2.48$ & $2.086 \pm .38$ & Significant $(\mathrm{p} \leq 0.044)$ \\
\hline $\begin{array}{l}\text { Serum creatinine in } \\
\mathrm{mg} / \mathrm{dl}\end{array}$ & $0.726 \pm 0.913$ & $0.755 \pm 0.198$ & $\begin{array}{l}\text { Not Significant } \\
(\mathrm{p} \leq 0.271)\end{array}$ \\
\hline
\end{tabular}

In our study majority of the preeclamptic women (80\%) were below 25 years. $56 \%$ of the women were primigravida. Mean systolic blood pressure in preeclamptic women was $158.2016 \pm .142 \mathrm{mmHg}$ while in 
normotensive women was $120.802 . \pm 740 \mathrm{mmHg}$ with $\mathrm{p}$-value $<0.0001$ Mean diastolic blood pressure in pre eclamptic group was $103.00 \pm 10.35 \mathrm{mmHg}$ while in normotensive women it was $74.32 \pm 2.21 \mathrm{mmHg}$. p-value was $<0.000$. Mean $\beta$ - hcg level in preeclamptic women was $27,802.51 \pm 2324.46 \mathrm{mIU} / \mathrm{L}$ while in normotensive pregnant women mean $\beta$ - hcg level was $12551.08 \pm 1624.28 \mathrm{mIU} /$ Lwith $\mathrm{p}$-value $<0.001$.

$94 \%$ of preeclamptic women have triglycerides level $>150 \mathrm{mg} / \mathrm{dl}$ while only $4 \%$ of normotensive women have triglyceride level $>150 \mathrm{mg} / \mathrm{dl}$. Compared to $84 \%$ of preeclamptic women only $2 \%$ of normotensive women have cholesterol level $>200 \mathrm{mg} / \mathrm{dl}$. Mean triglyceride level in preeclamptic and normotensive pregnant women was $281.96 \pm 99.84 \mathrm{mg} / \mathrm{dl}$ and $124.48 \pm 18.671 \mathrm{mg} / \mathrm{dl}$ respectively with a p-value $<0.001$. Mean total cholesterol level in preeclamptic and normotensive women was $242.386 \pm 52.032 \mathrm{mg} / \mathrm{dl}$ and $143.33 \pm 25.032 \mathrm{mg} / \mathrm{dl}$ respectively with $\mathrm{p}$-value $<0.001$.

$36 \%$ of preeclamptic women have platelets count $<2.2$ lacs/dl while only $10 \%$ of normotensive women have platelets count $<2.21$ acs $/ \mathrm{dl}$. Serum creatinine value $>1 \mathrm{mg} / \mathrm{dl}$ was present in $26 \%$ of normotensive women while no normotensive pregnant women have serum creatinine value $>1 \mathrm{mgdl}$. $\mathrm{P}$ value for platelets and serum creatinine were $\leq 0.044$ and $\leq 0.271$ respectively

\section{Discussion}

In pre-eclampsia the rise of blood pressure is due to vasoconstriction and impaired angiogenesis leading to hypoxia and hyperplasia of trophoblastic cells which causes hyper secretion of placental hormone ultimately leading to high level of circulating $\beta$-hCG. High-level of circulating $\beta$-hCG are found in preeclampsia. As pre-eclampsia is probably a trophoblastic disorder, elevated $\beta$-hCG is thought to reflect early placental damage or dysfunction .

In our study mean age for preeclampsia was $23.24 \pm 3.941$ and for normotensive patients it was 25.40 \pm 3.676. p-value was 0.645 . Kanika Mandi Chaudhary also did not found significant difference between the mean age of preeclampsia and normotensive pregnant women(1). This shows higher incidence of preeclampsia in younger women, but the age in which preeclampsia occur has not much difference than normotensive pregnant women. In our study there was higher incidence of preeclampsia in primigravida (56\%).

Our study show that mean $\beta$ hCG level in preeclamptic women was $27,802.51 \pm 2324.46 \mathrm{mIU} / \mathrm{L}$ which was significantly higher then pregnant normotensive women(12,551.08 \pm 1624.28$)$ p-value was $<0.001$. The result of our study showed that there was significant difference between $\beta$ hcg level of pregnant normotensive and preeclamptic women and the level of $\beta$ hcg was higher in severe preeclampsia. Study of Dayal Meena,Gupta Paru(9) also shows higher level of $\beta$ hcg in preeclamptic women 16,130.2(.2.5 MoM) than normotensive pregnant women with $\beta$ hcg level 4,621.8(0.95MoM) with p-value $<.001$. Another study conducted by Kanika Mandi, Munmun Das et.al(1) also support our findings. It seems that $\beta$ hcg level in case of preeclampsia, in which there is placental perfusion disorder and severe damaging to placental cells. Therefore measuring the $\beta$ hcg level may be an early sign for the diagnosis of the disease and prove to be an indicator of severity of the disease.

Mean triglyceride level in preeclamptic and normotensive pregnant women was $281.96 \pm 99.84 \mathrm{mg} / \mathrm{dl}$ and $124.48 \pm 18.671 \mathrm{mg} / \mathrm{dl}$ respectively with a p-value $<.001$. Mean total cholesterol level in preeclamptic and normotensive women was $242.386 \pm 52.032 \mathrm{mg} / \mathrm{dl}$ and $143.33 \pm 25.032 \mathrm{mg} / \mathrm{dl}$ respectively with p-value $<0.001$. Thus our study show a significant difference of level of triglyceride and cholesterol between preeclampsia and normotensive pregnant women. In the Study conducted by Zainab G. Hussein(10) triglyceride and total cholesterol level in preeclamptic and normotensive women $302.38 \pm 29.30,252.63+-9.91$ and $251.75 \pm 23.21$, $180.38 \pm 7.85$ respectively with a $p$-value $<0.05$. These findings are similar to our study.

Mean platelets count and serum creatinine in preeclamptic and normotensive pregnant women were $2.086 \pm 0.38, \quad 0.755 \pm 0.198 \mathrm{mg} / \mathrm{dl}$ and $2.474 \pm 0.248,0.7262 \pm 0.913$ respectively. p-value for platelets and serum creatinine was $<.044$ and $<.271$ respectively. In our study Platelets count has significant difference between preeclampsia and normotensive pregnant women but serum creatinine did not have significance between both group. In the study of Shaifali Dadhich et al(11) there is significant difference between the level of platelets count in preeclampsia and in normotensive. Study of razia sultana et al(8) also support significance of platelets count for the prediction of preeclampsia. In their Study, Magna Manjareeka (12) weerasekera D S and Peiris H.(13) and Zainab H Huaissen (10) did not found significanct difference between serum creatinine level of preeclampsia and norrmotensive women thus preclude use of serum creatinine value for prediction of preeclampsia.

\section{Conclusion}

Mean $\beta$ hCG level tends to be significantly higher in preeclamptic women as compared to normotensive pregnant women. $\beta$ hCG level might reflect degree of disordered activity of placental trophoblast in PIH . Thus assessment of $\beta$ hCG level may be helpful in prediction of of PIH and prevention of its complication. It is also prove to be an indicator of severity of disease. 
Level of triglyceride, cholesterol and platelets count also have significant difference between preeclampsia and normotensive pregnant women. thus these biochemical markers can also used for prediction of preeclampsia.

\section{Bibliography}

[1]. Kanika Mandi Chaudhury, Munmun Das, Sulekha Ghosh, Debasis Bhattacharya, Tapan Kumar Ghosh : Value of serum beta hcg in pathogenesis of preeclampsia. Journal of clinical Gynaecology and obstetrics.volume 1, number 4-5, oct. 2012, pg 71-75

[2]. Duley L. The global impact of pre-eclampsia and eclampsia. Semin Perinatol. 2009;33(3):130-7.

[3]. Preeclampsia and maternal mortality; A global burden; may 2013

[4]. Remzi Gondeniz, Erdal Areguloglu, Nursal Bazolglu, Ozcan Balat; Elevated serum $\beta$ hcg level in severe preeclampsia; Turk J Med Sci 30(200) 43-45

[5]. Uotila J T, Tuimala R J, Aarnio TM: Finding on lipid peroxidation and antioxidant function in hypertensive complication of pregnancy; Br. J. obstet and gynecol, 1993; 100: 270-276

[6]. wickens D, Wilkins MH, Lunec J, ball G, Dormandy TJ: Free radical oxidation (peroxidation) products in plasma in normal and abnarmal pregnancy. Ann. Clin. Biochem. 1981; 18: 158-159.

[7]. Winkler K, Wetzka B, Hoffmann MM, Fraiedrich I, Kinner M, Manfred WB, Zahradnik H, Wieland H, Winfried M: TriglycerideRich Lipoproteins Are Associated with Hypertension in Preeclampsia ; The J of Clin Endocrinal and Metabol 2003; 88: 1162 -1166.

[8]. Razia Sultana, S. M. Fazlul Karim, Farhana Atia, Shahnila Ferdousi, Selina Ahmed: Platelet Count In Preeclampsia.. J. Dhaka National Med. Coll. Hos. 2012; 18 (02): 24-26

[9]. Dayal Meena , Gupta Parul, Verma Manju, Ghosh UK, Bhargava Anudita : Role of second trimester maternal serum markers as prediction of preeclampsia ; The Journal of Obstetrics and Gynaecology in India January/februa ry $2011 \mathrm{pg} 38-41$.

[10]. zainab G Huaissen: Study of liver and kidney function in nonpregnant, pregnant, and preeclamptic women: J bagdad for Sci volume 9(2), 2012.

[11]. Dadhich, Shaifali, Agrawal Sudesh, Soni, Monica,Choudhary Rekha, Jain Rashmi, Sharma Saroj, Saini, Sharad Lata: Predictive Value of Platelet Indices in Development of Preeclampsia; Journal of South Asian Federation of Obstetrics \& Gynecology; JanApr2012, Vol. 4 Issue 1, p17

[12]. Magna Manjareeka, Sitikantha nanda: Elevated levels of serum uric acid, creatinine or urea in preeclamptic women. Int J Med Sci Public Health. Year: 2013;2(1) :43-47 Volume: 3, Issue: 5

[13]. Weerasekera DS, Peiris H: The significance of serum uric acid, creatinine and urinary microprotein levels in predicting preeclampsia ; J Obstet Gynaecol. 2003 Jan;23(1):17-9 